\title{
Peningkatan Kompetensi Menyusun dan Mengajarkan Soal Cerita Matematika bagi Guru SD Pedesaan Sumarwati $^{1}$, Budiyono ${ }^{2}$ \\ 1,2 Universitas Sebelas Maret \\ Email:watik_uns@ymail.com¹,budiyono53@yahoo.com
}

\begin{abstract}
ABSTRAK
Masalah yang dihadapi guru sekolah dasar di Kecamatan Cepogo, Kabupaten Boyolali yang termasuk pedesaan adalah siswa sulit memahami isi soal cerita dalam buku Matematika karena bahasa dan konteksnya tidak sesuai dengan kompetensi mereka. Sementara itu, guru kesulitan menyusun soal cerita yang sesuai dengan karakteristik kebahasan siswanya serta mengajarkannya dengan metode komunikatif. Tujuan pengabdian ( $\mathrm{IbM}$ ) ini untuk meningkatkan kompetensi guru dalam (1) menyusun soal cerita yang sesuai dengan karakteristik bahasa dan konteks siswanya serta (2) mengajarkan soal cerita dengan metode komunikatif sehingga membantu siswa untuk memahami isi soal cerita. Yang menjadi subjek (mitra) adalah 30 guru kelas 1, 2, 3. Pendekatan yang diterapkan adalah pendekatan partisipatif dengan teknik modelling, simulasi, dan praktik kelas. Hasil pelatihan dan pendampingan penyusunan soal cerita menunjukkan lebih dari $70 \%$ guru dapat membuat soal cerita Matematika yang sesuai kriteria, sedangkan pada guru yang lain, sebagian soal cerita buatannya tidak sesuai kriteria, misalnya kalimat terlalu panjang, tidak menggunakan aktor dan setting, serta tidak memuat nilai karakter positif. Hasil pelatihan dan pendampingan praktik mengajarkan soal cerita menunjukkan lebih dari $60 \%$ guru dapat mengajarkan soal cerita buatannya secara komunikatif dengan teknik menerjemahkan (dalam bahasa Jawa) dan menceritakan sehingga siswa dapat memahami isi soal soal dan membuat persamaan Matematika secara benar.
\end{abstract}

Kata kunci: penyusunan dan pengajaran; soal cerita Matematika; sekolah dasar; pedesaan

\section{The Improvement of Composing and Teaching Word Problem Competencies for Rural Elementary School Teachers}

\begin{abstract}
The problem faced by primary school teachers in Cepogo Subdistrict, Boyolali District which is rural area, is that it is difficult for students to understand word problems in the Mathematics book because the language and context are not in line with their competencies. Meanwhile, the teacher has difficulty creating word problem that are appropriate to the students' language characteristics and teaching them using communicative methods. The purpose of this devotion (IbM) is to improve teacher competence in (1) ccomposing word problem that are in accordance with the characteristics of the language and context of the students and (2) teaching word problems with communicative methods so that it helps students to understand the content of problems. The subjects (partners) were 30 teachers in grades 1, 2, 3. The approach applied was a participatory approach with modeling techniques, simulations and classroom practices. The results of the training and mentoring for the preparation of word problems showed that more than $70 \%$ of the teachers could compose Mathematics word problems that were in accordance with the criteria, whereas in other teachers, some of the stories they made were not in accordance with the signs, ie the sentences were too long, not use actors and settings, and do not contain positive character. The results of training and practical assistance teaching word problems show that more than $60 \%$ of teachers can teach the
\end{abstract}


word problems that she made communicatively by translating techniques (in Javanese) and telling stories so students can make mathematical equations correctly.

Keywords: composing and teaching; mathematics word problems; primary school; rural

\section{PENDAHULUAN}

Dalam pelajaran Matematika terdapat dua jenis soal, yaitu soal cerita dan soal noncerita. Bagi guru SD di pedesaan, soal cerita dipandang lebih sulit diajarkan pada siswa dibandingkan soal noncerita. Untuk memperjelas perbedaan kedua jenis soal matematika tesebut, pada Tabel 1 disajikan contohnya.

Tabel 1. Jenis Soal Matematika di SD

\begin{tabular}{|c|l|}
\hline Jenis Soal & \multicolumn{1}{|c|}{ Contoh Soal } \\
\hline Soal Noncerita & $576-138=$ \\
Soal Cerita & $\begin{array}{l}\text { Pedagang buah memiliki 576 buah mangga. } \\
\text { Sebanyak 138 buah telah ia jual. } \\
\text { Berapa buah mangga yang masih ada? }\end{array}$ \\
\hline
\end{tabular}

Ilustrasi mengenai contoh serta proses pemecahan soal dalam pelajaran Matematika di atas menunjukkan bahwasoal cerita memerlukan proses pemecahan lebih panjang dibandingkan soal noncerita. Pada soal cerita, ada kegiatan membuat persamaan matematika lebih dahulu sebelum menghitung hasilnya. Budiyono (2008) menamai kegiatan ini sebagai kegiatan menerjemahkan soal cerita menjadi persamaan matematika.

Memang, bagi para siswa, baik di kota maupun desa, soal cerita lebih sulit dipecahkan sehingga kemampuannya dalam mengerjakan soal itu lebih rendah dibandingkan soal noncerita. Namun demikian, ada perbedaan tingkat kesulitan yang dialami siswa di perkotaan dan pedesaan dalam memecahkan soal cerita. Jika kesulitan memecahkan soal cerita mulai dialami siswa kelas 4 di kota, kesulitan tersebut terjadi sejak kelas 1 bagi siswa SD di desa (Sukamto, Sukardjono, \& Ngatoilah, 2008). Analisis lebih lanjut dari Sumarwati dan Budiyono (2015) menemukan bahwa fenomena itu dapat dikaitkan dengan angka partisipasi kasar (APK) TK di Indonesia yang baru mencapai $40,40 \%$ dan itu didominasi penduduk di perkotaan. Adapun hampir 80\% anak di desa tidak melalui pendidikan taman kanak-kanak (TK). Dengan demikian, pengalaman belajar anak di pedesaan dimulai ketika masuk SD, termasuk belajar Bahasa Indonesia mengingat dalam kesehariannya mereka menggunakan bahasa ibu (daerah).

Sudah barang tentu, kondisi seperti di atas menjadi permasalahan tersendiri bagi guru kelas rendah sekolah dasar di kawasan pedesaan, seperti di Kecamatan Cepogo, Kabupaten Boyolali. Berdasarkan hasil wawancara dengan guru-guru kelas 1, 2, dan 3 SD Negeri Bakulan, SD Negeri Mliwis, SD Negeri Randu, dan SD Negeri Jelok 2 diperoleh informasi bahwa sebagian besar siswa di sekolah mereka juga mengalami kesulitan dalam mengerjakan soal cerita matematika. Siswa terutama kesulitan untuk menentukan jenis operasi hitung (penjumlahan, pengurangan, perkalian, pembagian) 
yang digunakan untuk membuat persamaan matematika. Oleh karena itu, menurut guru-guru kelas 1, 2, dan 3 di SD Negeri Randu setiap diberi tugas mengerjakan soal cerita, siswa bertanya kepada guru operasi hitung apa yang dimaksud dalam soal, bahkan tak jarang mereka bertanya sebelum guru selesai membacakan soal cerita dalam buku teks Matematika. Pembacaan soal dilakukan karena siswa belum lancar membaca.

Dari hasil analisis para guru diperoleh kesimpulan bahwa faktor penyebab timbulnya kesulitan dalam membuat terjemahan soal cerita ke dalam persamaan matematika, selain disebabkan oleh rendahnya penguasan konsep-konsepmatematikapadasiswa, juga oleh kesulitan siswa dalam memahami bahasa yang digunakan pada soal cerita. Ini dapat dikaitkan dengan fenomena bahwa saat belajar matematika, siswa juga tengah mulai belajar bahasa Indonesia. Dinyatakan guru SD Negeri 2 Jelok dan guru SD Negeri Paras 1 bahwa siswanya sering bingung dengan makna katakata berbahasa Indonesia dalam soal cerita karena berbeda dengan makna yang dikenalnya. Misalnya kata menjualpada soal cerita memiliki makna 'penjumlahan' atau berelasi dengan operasi hitung penjumlahan $(+)$, kata memetik (bunga) berelasi dengan operasi hitung pengurangan ( -), frasa lebih tinggi berelasi dengan operasi hitung penjumlahan $(+)$, serta frasa lebih muda berelasi dengan pengurangan $(-)$. Dengan demikian, adanya perbedaan makna kata pada bahasa natural dengan bahasa matematika itulah yang menjadi masalah.

Menurutguru SDNegeriBakulan, SD Negeri Randu, dan SD Negeri Jelok 2 selama ini mereka telah berupaya untuk mengatasi permasalahan yang dialami siswa dalam mengerjakan soal cerita matematika. Mereka mengatasinya dengan mengadakan media gambar dan benda nyata di kelas, misalnya batu kerikil dan biji-bijian. Akan tetapi, penggunaan media tersebut lebih ditujukan untuk membantu menemukan hasil hitung persamaan matematika. Adapun tindakan untuk membantu siswa agar lebih cepat dalam mengerjakan soal cerita adalah dengan membacakan soal-soal yang terdapat dalam buku teks Matematika. Ini dilakukan guru karena sebagian siswa kelas 1 dan 2 belum lancar membaca. Dengan demikian, berdasarkan uapaya-upaya tersebut dapat dinyatakan bahwa belum ada upaya tepat yang dilakukan guru untuk mengatasi kesulitan siswa dalam memahami soal cerita.

Dari hasilwawancara dengan guru kelas 1, 2, dan 3 di SD Negeri Jelok 1 dan SD Negeri Tumang 3 diperoleh informasi bahwasebenarnyaguruingin menyusun sendiri soal cerita sebagai materi dalam pelajaran Matematika, tetapi tidak tahu cara membuat soal yang baik. Oleh karenanya, mereka menggunakan soal cerita dari buku teks Matematika dan LKS terbitan tahun 2012 dalam pembelajaran karena buku guru terbitan baru memuat sangat sedikit soal cerita. Padahal, berdasarkan hasil penelitian Sumarwati (2014) ditemukan bahwa 
hampir $60 \%$ soal cerita dalam buku teks Matematika kelas 1, 2, dan 3 yang telah lolos penilaian BSNP tahun 2008 tidak memenuhi standar dari aspek kebahasaan, struktur teks, dan konteksnya. Misalnya, kalimatnya terlalu panjang, kalimat ambigu (menimbulkan multitafsir), konteks soal tidak terdapat dalam pengalaman nyata siswa, dan penanaman nilai karakter kurang diperhatikan. Untuk memberi gambaran permasalahan dalam soal cerita pada buku teks Matematika yang banyak digunakan di wilayah Kecamatan Cepogo, di bawah ini disajikan contoh-contohnya.

(1) jari kaki depan hamster ada 4 jari belakang hamster 1 lebih banyak berapa banyak jari kaki belakang hamster

(Soal kelas 1)

(2) hamster beranak setelah 16 hari hamster oki beranak 2 hari lebih lama setelah berapa hari hamster oki beranak

(Soal kelas 2)

Padakeduasoal ceritadiatas, yang menjadi masalah adalah digunakannya topik tentang hamster. Ini disebabkan binatang tersebut tidak dijumpai di pedesaan, sehingga menurut beberapa guru di Kecamatan Cepogo, mereka perlu menjelaskan terlebih dahulu karakteristik hamster agar siswa tidak kesulitan dalam memahami maksud soal. Namun demikian, ada guru yang tidak memiliki pengetahuan tentang hamster sehingga tidak bisa memberi penjelasan kepada siswa. Sudah barang tentu hal tersebut menjadi kesulitan tersendiri bagi siswa. Kesulitan itu bisa timbul karena binatang hamster tidak ada dalam pengalaman nyata mereka sehingga tidak dapat mengkontruksi peristiwa yang ada dalam soal. Akan lebih nyata jika digunakan objek binatang yang familiar bagi siswa pedesaan, misalnya kelinci. Objek lain dalam soal cerita yang menjadi sumber kesulitan siswa kelas 1 dan 2 adalah tentang meronce manik-manik, halte bis kota, tukang loak, dan les piano

Dari struktur wacananya, sebuah soal cerita terdiri atas tiga bagian, yaitu bagian pembuka (biasanya kalimat pertama), bagian isi (biasanya pada kalimat kedua), dan bagian pertanyaan (biasanya pada kalimat ketiga) seperti soal nomor (3) di bawah ini

(1) Serangga mempunyai tubuh kecil, (BAGIAN PEMBUKA) tapi serangga dapat mengangkat benda 20 kali berat tubuhnya. (BAGIAN ISI) Berapa gram berat yang dapat diangkat serangga dengan berat 5 gram? (BAGIAN PERTANYAAN)

Akan tetapi, seringkali soal cerita tidak memuat tiga bagian secara lengkap da nada pula penggabungan bagian-bagian tersebut sehingga beberapa informasi menumpuk pada satu kalimat dan itu bisa menjadi sumber kesulitan tersendiri bagi siswa. Seperti pada soal cerita (3) di atas, bagian pembuka dan bagian isi digabung menjadi satu, yaitu kalimat pertama yang terdiri atas dua kalimat tunggal. Agar terpisah antarbagiannya, susunannya harus dibuat sebagai berikut "Serangga mempunyai tubuh kecil. Tapi serangga dapat mengangkat benda 20 kali berat tubuhnya.Berapa gram berat yang dapat diangkat serangga dengan berat 5 gram? Selain itu, terhadap 
soal (3) di atas, menurut guru ada katakata yang sulit dipahami siswa, yaitu 'mengangkat benda'. Siswa bertanya "Serangga tidak punya tangan, tapi mengapa bisa mengangkat benda". Dapat dinyatakan bahwa dalam logika anak-anak, soal tersebut tidak logis.

Menurut Raharjo, Ekawati, dan Rudiyanto (2009), ada sejumlah keunggulan dengan guru membuat sendiri soal cerita matematika, di antaranya: (1) Buku teks tidak lagi menjadi titik sentral pembelajaran, sehingga materi pembelajaran lebih variatif; (2) Soal cerita buatan guru bisa menjadi materi yang lebih menarik dibandingkan yang termuat dalam buku teks. Hal ini disebabkan soal cerita buatan guru bersifat baru; (3) Penyusunan soal cerita oleh guru dapat menciptakan suasana yang menyenangkan apabila dapat mengakomodasiminat dankompetensi siswa; dan (4) Dengan soal buatan sendiri, guru lebih dapat mengkreasi cara penyampaiannya secara inovatif pada siswa untuk mendukung tercapainya tujuan pembelajaran

Berdasarkan paparan di atas, kurangnya komptensi guru dalam menyusun soal cerita akan menutup peluang-peluang positif di atas. Di lain pihak, Kurikulum KTSP maupun Kurikulum 2013 yang mengarah pada pembelajaran berbasis kreativitas harus didukung dengan keberadaan sumber daya manusia yang kreatif. Dengan demikian, sangat penting bagi guru-guru sekolah dasar di Kecamatan Cepogo, Kabupaten Boyolali untuk meningkatkan kemampuannya dalam menyusun dan mengajarkan soal cerita untuk menunjang prestasi Matematika siswa. Dengan bekal kemampuan tersebut diharapkan guru juga makin kreatif dalam pembelajaran. Oleh karena itu, pelatihan dan pendampingan penyusunan soal cerita yang komunikatif serta pengajarannya penting untuk dilakukan.

Berpijak pada paparan di atas, dapat didentifikasi permasalahan yang terjadi dalam pembelajaran Matematika, yaitu (1) Guru kelas 1, 2, dan 3 SD di Kecamatan Cepogo menggunakan buku teks atau LKS (lembar kerja siswa) sebagai satusatunya sumber dalam pembelajaran soal cerita matematika; (2) Guru belum mampu menyusun soal cerita matematika yang baik; (3) Guru belum mampu mengajarkan soal cerita matematika secara komunikatif sehingga memudahkan siswa dalam memahamiisisoal,menerjemahkannya menjadi persamaan matematika, serta menemukan hasil hitung secara tepat; dan (4) Soal cerita yang terdapat dalam buku teks Matematika kurang relevan (dalam hal struktur bahasa, struktur teks dan konteks) dengan kondisi siswa di pedesaan

Secara umum tujuan kegiatan penerapan Ipteks bagi masyarakat (IbM) ini adalah untuk meningkatan kompetensi guru SD di kawasan pedesaan dalam pembelajaran Matematika. Adapun tujuan khusunya adalah meningkatkan kompetensi guru dalam (1) menyusun soal cerita Matematika sesuai karakteristik keba-hasaan dan konteks siswa SD di KecamatanCepogo, Boyolali sehingga mudah dipahami dan (2) mengajarkan soal cerita Matematika buatan sendiri dengan metode komuniktif sehingga membantu siswa dalam memahami isi soal cerita dan dapat membuat 
persamaan matematika secara tepat.

\section{METODE}

\section{Pendekatan Kegiatan}

Dalam penerapan Ipteks bagi masyarakat ini diterapkan pendekatan partisipatif melalui kegiatan pelatihan dan pendampingan. Kegiatan dilakukan dengan mementingkan partisipasi peserta. Pendekatan partisipatif ini menekankan pada proses kegiatan di mana kegiatan belajar dalam pelatihan dibangun atas dasar partisipasi aktif peserta dalam semua kegiatan.

Teknik yang diterapkan meliputi teknik modelling, simulasi, dan praktik kelas. Teknik modelling dilakukan pada saat pelatihan, yaitu dengan memberi contoh-contoh penyusunan dan pengajaran soal cerita matematika, kemudian guru mencoba mengikuti langkah tersebut. Teknik simulasi diterapkan pada saat pelatihan mengajarkan soal cerita dengan metode komunikatif, yaitu memperagakan penyusunan soal cerita oleh guru secara peer-teaching. Teknik praktik kelas diterapkan pada pengajaran soal cerita buatan guru dengan metode komunikatif di kelas masing-masing.

\section{Partisipan}

Penerapan Ipteks bagi masyarakat ini dilakukan di Kecamatan Cepogo yang terletak $\pm 10 \mathrm{~km}$ dari pusat kota Kabupaten Boyolali. Di kecamatan ini terdapat penduduk miskin yang mencapai hampir 30\%) dari 43 ribu penduduknya (Data Penduduk Kab. Boyolali, 2015). Oleh karena itu, banyak orang tua yang tidak mampu memasukkan anaknya ke pendidikan prasekolah (taman kanak-kanak/ PAUD).

Di Kecamatan Cepogo terdapat 48 sekolah dasar/MI yang tercakup dalam enam kelompok kerja guru (KKG). Di antara keenam gugus tersebut, guru-guru Gugus Dipoengoro 2 dan Hasanudin 2 jarang mendapat pelatihan atau kegiatan lain untuk meningkatkan kompetensinya sebagai pendidik. Oleh karena itu, tim memilih guru-guru pada dua gugus tersebut sebagai sasaran kegiatan pengabdian ini. Subjek yang menjadi sasaran kegiatan dibatasi untuk guru kelas 1, 2, dan 3. Adapun peserta IbM meliputi guru dari 5 SD pada Gugus Diponegoro 2 dan 5 SD pada Gugus Hasanudin 2. Karena itu, yang menjadi sasaran kegiatan ini adalah guru kelas 1, 2, dan 3 dari $10 \mathrm{SD}$ sehingga semuanya berjumlah 30 guru.

\section{Materi Kegiatan}

Sesuai dengan tujuan kegiatan pengabdian ini, yaitu memberi pelatihan dan pendampingan penyusunan soal cerita dan pengajarannya dengan metode komunikatif, sehingga materi yang disampikan meliputi kedua hal tersebut. Materi tersebut berupa kriteria penyusunan soal cerita dan metode pengajaran soal cerita secara komunikatif yang didasarkan hasil penelitian Sumarwati, Budiyono, \& Atikah (2018) dan Sumarwati (2014).

\section{HASIL DAN PEMBAHASAN}

PenerapanIpteks bagiMasyarakat ini mencakup tiga kegiatan, yaitu pelatihan penyusunan soal cerita Matematika, pelatihan pengajaran, dan pendampingan pengajarannya di kelas. Pelatihan dan pendampingan penyusunan soal cerita dilaksanakan 
pada workshop I dan II. Pelatihan dan simulasi pengajaran soal cerita dilaksanakan pada workshop III. Adapun pendampingan praktik pengajaran dilaksanakan di kelas masing-masing. Adapun hasilkegiatan tersebut adalah sebagai berikut ini.

\section{Kinerja guru dalam penyusunan soal cerita matematika}

Pelatihan dan pendampingan penyusunan soal cerita direalisasikan dalam dua kali workshop, yaitu workshop I untuk operasi hitung penjumlahan dan pengurangan, sedangkan workshop II untuk operasi hitung perkalian dan pembagian. Adapun kriteria soal cerita yang harus dipenuhi termuat pada tabel 2 .

Tabel 2. Kriteria soal cerita

\begin{tabular}{ll}
\hline No & \multicolumn{1}{c}{ Kriteria } \\
\hline 1 & $\begin{array}{l}\text { Menggunakan kata yang familiar (kata yang tidak } \\
\text { familiar diganti, misalnya kontainer diganti truk) }\end{array}$ \\
\hline 2 & $\begin{array}{l}\text { Menggunakankalimat aktifdan pasif secara berkombinasi } \\
\text { (bila memungkinkan kalimat pasif dibuat menjadi aktif, } \\
\text { misalnya lima kelereng diambil Budi dibuat menjadi } \\
\text { Budi mengambil 5 kelereng) }\end{array}$ \\
\hline 3 & $\begin{array}{l}\text { Jumlah kata pada setiap kalimat: } \\
\text { kelas 1-2, kalimat terdiri atas 3-5 kata; } \\
\text { kelas 3-4, kalimat terdiri atas 3-9 kata; } \\
\text { kelas 5-6, kalimat terdiri atas 3-12 kata. }\end{array}$ \\
\hline 4 & $\begin{array}{l}\text { Jumlah kalimat pada soal (satu paragraf) } \\
\text { kelas 1-2, tiap soal terdiri atas 3-6 kalimat; } \\
\text { kelas 3-4, tiap soal terdiri atas 3-8 kalimat; } \\
\text { kelas 5-6, tiap soal terdiri atas 3- 12 kalimat }\end{array}$ \\
\hline 5 & $\begin{array}{l}\text { Kalimat kondisional (menggunakan jika, } \\
\text { apabila) dibuat kalimat-kalimat tunggal }\end{array}$ \\
\hline 6 & $\begin{array}{l}\text { Menggunakan kata kerja yang ada dalam pengalaman } \\
\text { siswa dan bernilai positif memberikan keteladanan }\end{array}$ \\
\hline 7 & $\begin{array}{l}\text { Menghindari penggunaan nama/objek simbolik dan } \\
\text { abstrak (kota C dibuat menjadi Kota Cirebon, Bapak B } \\
\text { menjadi Bapak Budi) }\end{array}$ \\
\hline 8 & $\begin{array}{l}\text { Menggunakan multiaktor yang memiliki hubungan } \\
\text { keluarga (familiar) pada soal yang memuat frase "lebih } \\
\text { banyak" dan "lebih sedikit" }\end{array}$ \\
\hline 9 & $\begin{array}{l}\text { Menggunakan tiga komponen wacana secara lengkap } \\
\text { (mencakup komponen pendahuluan, komponen } \\
\text { peristiwa, dan komponen pertanyaan) }\end{array}$ \\
\hline 10 & $\begin{array}{l}\text { tidak mengarah pada SARA, kekasaran, pornografi, } \\
\text { pelecehan, bias gender dan sebagainya yang dapat } \\
\text { mengganggu dan mempengaruhi pikiran dan perasaan } \\
\text { peserta ddik secara negatif. }\end{array}$ \\
\hline & \\
&
\end{tabular}

Kegiatan workshop meliputi langkah berikut: (1) penyampaian kriteria dan teknik penyusunan soal cerita dan contoh-contohnya; (2) penugasan pada guru untuk membuat 2 buah soal cerita pada masing-masing operasi hitung; (3) penayangan beberapa soal cerita buatan guru perwakilan kelas 1, 2, dan 3 ; (4) pembahasan soal cerita buatan guru yang ditayangkan; dan (5) penugasan dan pendampingan kepada guru dalam penyusunan soal cerita untuk $2 \mathrm{KD}$ tentang operasi hitung penjumlahan, pengurangan, perkalian, dan pembagian dengan masing-masing KD sebanyak 10 soal. Kegiatan yang terakhir dilanjutkan oleh guru di rumah dalam waktu satu minggu, kemudian mengirimkannya pada tim melalui email atau melalui koordinator. Soal cerita buatan guru tersebut selanjutnya dievaluasi dari aspek kebahasaan, struktur teks, dan unsur narasi.

Dari pekerjaan 30 guru (10 guru kelas 1, 10 guru kelas 2, dan 10 guru kelas 3) diperoleh data kinerjanya pada Tabel 3.

Tabel 3. Kinerja guru dalam penyusunan soal cerita Matematika

\begin{tabular}{lccc}
\hline \multirow{2}{*}{ Aspek dinilai } & \multicolumn{2}{c}{$\begin{array}{c}\text { Guru yang dapat membuat } \\
\text { soal cerita sesuai kriteria }\end{array}$} \\
\cline { 2 - 4 } & $\begin{array}{l}\text { G u r u } \\
\text { kelas 1 }\end{array}$ & $\begin{array}{c}\text { G u r u } \\
\text { kelas 2 }\end{array}$ & $\begin{array}{c}\text { G u r u } \\
\text { kelas 3 }\end{array}$ \\
\hline Bahasa komunikatif & $90 \%$ & $70 \%$ & $70 \%$ \\
\hline Komponen teks lengkap & $100 \%$ & $100 \%$ & $80 \%$ \\
\hline Unsur narasi kontekstual & $80 \%$ & $70 \%$ & $70 \%$ \\
\hline Nilai karakter positif & $80 \%$ & $80 \%$ & $70 \%$ \\
\hline Relevan dengan KD & $80 \%$ & $80 \%$ & $70 \%$ \\
\hline
\end{tabular}

Data pada tabel di atas menunjukkan sebagian besar $(70 \%$ lebih) guru kelas 1, 2 dan $3 \mathrm{SD}$ di Kecamatan Cepogo umumnya memiliki kompetensi yang baik dalam menyusun soal cerita dengan notasi hitung penjumlahan, pengurangan, 
perkalian dan pembagian. Sebagian kecil lainnya belum dapat membuat soal cerita sesuai kriteria. Kesulitan yang paling banyak dialami adalah menerapkan kaidah kekomunikatifan bahasa, misalnya menggunakan kalimat terlalu panjang, kata-kata bermakna abstrak, dan kata-kata kompleks. Selain itu, sebagian guru juga belum mampu menyusun soal cerita dengan konteks yang sesuai lingkungan siswa, misalnya suhu di Kutub Utara, mainan lego, menerbangkan balon udara, sunkis.

Berikut ini contoh soal cerita buatan guru yang memenuhi kriteria.

(1) rio punya akuarium ada 15 ikan merah ada 5 ikan kuning berapa semua ikan (penjumlahan untuk kelas 1)

(2) laili rajin membantu ibu laili mencuci 23 gelas panjang laili juga mencuci 24 gelas pendek berapa banyak gelas semuanya (penjumlahan untuk kelas 2)

(3) Di Cepogo udaranya sejuk Kalau malam suhunya $22^{\circ}$ Siang suhunya $12^{\circ}$ lebih panas Berapa derajat suhu siang hari? (penjumlahan untuk kelas 3)

(4) nanda suka bunga nanda menanam 17 bunga ada 2 bunga yang mati berapa bunga nanda sekarang (pengurangan untuk kelas 1)

(5) anita berjalan ke sekolah jarak ke sekolah 200 meter setelah berjalan 120 meter anita berhenti

berapa meter lagi jarak ke sekolah (pengurangan untuk kelas 2)

(6) Om Bono adalah adik ayah Om Bono 7 lebih muda dari ayah Usia ayah 38 tahun Berapa tahun usia om Bono? (pengurangan untuk kelas 3)
(7) ibu ke pasar ibu membeli 2 dos gelas tiap doa berisi 6 gelas berapa gelas semuanya (perkalian untuk kelas 1)

(8) pak bejo peternak ikan yang sukses.

pak bejo punya 6 kolam ikan ada 60 ikan pada tiap kolam berapa banyak ikan semuanya (perkalian untuk kelas 2)

(9) Mbah Maimun petani wortel Hasil panen wortel ada 16 keranjang Setiap keranjang ada $25 \mathrm{~kg}$ wortel Berapa $\mathrm{kg}$ wortel yang dipanen? (perkalian untuk kelas 3)

(10) pak yanto punya 20 kelinci pak yanto punya 4 kandang banyak kelinci setiap kandang sama

berapa banyak kelinci setiap kandang (pembagian untuk kelas 1)

(11) sofia suka membaca buku sofia punya 125 buku bacaan bukunya disimpan pada 5 rak tiap rak isinya sama berapa banyak buku tiap rak? (pembagian untuk kelas 2)

(12) Bu Guru membeli alat tulis Bu Guru membeli 180 buku Bu Guru juga membeli 204 pinsil Berapa lusin buku yang dibeli? Berapa lusin pinsil yang dibeli? (pembagian untuk kelas 3)

Adapun contoh soal yang tidak memenuhi kriteria sebagai berikut ini.

(13) hanik membeli 2 kue hanik membeli lagi 1 kue berapa kue hanik sekarang (penjumlahan untuk kelas 1)

(14) andre punya 25 kelereng andre minta kelereng andi 6 butir berapa jumlah kelereng andre (penjumlahan untuk kelas 2)

(15) Umur Sinta 17 tahun Umur Sinta 4 tahun lebih muda dari Santi 
Berapa tahun umur Santi? (penjumlahan untuk kelas 3)

Kriteria yang tidak terpenuhi soal nomor (13) adalah tidak memuat pendidikan karakter positif dengan menggunakan kata-kata membeli lagi kue yang merefleksikan perilaku konsumtif pada anak-anak. Pada soal (14), pengguaan andre minta kelereng andi 6 butir tidak memberikan konteks yang jelas untuk menunjuk notasi hitung penjumlahan karena meskipun andre minta belum tentu andi memberi. Adapun soal (15) merupakan contoh soal penjumlahan dengan makna perbandingan dengan topik usia. Lazimnya frase lebih muda untuk menunjuk operasi hitung pengurangan, sedangkan untuk operasi hitung penjumlahan adalah lebih tua, sehingga penggunaannya untuk operasi hitung penjumlahan akan membingungkan siswa kelas 3 SD.

(16) kakak menanam 28 bunga mawar bunga mawar kakak dicabut adik 12 buah.

berapa bunga mawar kakak sekarang (pengurangan untuk kelas 1)

(17) agus memelihara 28 ekor ayam. ada 15 ayam yang mati yang lainnya masih hidup. berapa selisih ayam yang mati dan yang hidup (pengurangan untuk kelas 2)

(18) Ayah mempunyai $\frac{9}{4}$ meter kayu. Sebanyak $\frac{5}{4}$ meter kayu dibuat kursi.

Sisanya disimpan.

Berapa meter kayu yang disimpan? (pengurangan untuk kelas 3)

Soal (16) tidak memenuhi kriteria karena menggunakan frasa dicabut adik 12 buah untuk menandai operasi hitung pengurangan. Perilaku tersebut tidak merefleksikan perilaku positif, yakni tidak mendukung gerakan senang menanam yang dicanangkan Pemerintah Kabupaten Boyolali. Soal nomor (17) tidak memenuhi kriteria karena penggunaan bagian soal yang lainnya masih hidup yang sebenarnya tidak diperlukan. Selain itu, penggunaan kata selisih yang identik dengan operasi hitung pengurangan pada kalimat tanya berapa selisih ayam yang mati dan yang hidup tidak mendorong siswa untuk memahami isi soal secara keseluuhan. Soal (18) tidak memberikan konteks yang realistik karena panjang kayu terlalu sedikit untuk membuat sebuah kursi.

(19) ada 5 plastik buah sunkis. setiap plastik memuat 8 buah sunkis

berapa banyak sunkis semuanya? (perkalian untuk kelas 1)

(20) Dalam ruang kelas 2 terdapat 6 baris kursi.

Setiap baris terdiri dari 5 kursi. Semua kursi telah diduduki siswa. Berapa jumlah siswa kelas 2? (perkalian untuk kelas 2)

(21) Andika akan mengadakan pesta Andika menyediakan 8 piring kue Setiap piring ada 12 buah kue Berapa tamu yang diundang? (perkalian untuk kelas 3)

Soal (19) tidak memenuhi kriteria karena konteks yang dibangun struktur kalimat dan struktur teks tidak jelas. Hal itu disebabkan digunakannya kata bungkusan yang tidak mengacu pada bungkusan coklat. Pada soal (20) juga terdapat ketidakjelasan konteks karena pada bagian pendahuluan 
membicarakan tentang kursi, namun menanyakan jumlah siswa pada bagian pertanyaan. Hal yang sama terdapat pada soal (21) yang mengangkat topik kue pada bagian peristiwa, namun menanyakan banyaknya tamu pada bagian pertanyaan.

(22) banyaknya coklat 12

banyaknya bungkusan ada 4

berapa banyak coklat di bungkusan

(pembagian untuk kelas 1)

(23) Sebanyak 72 orang naik angkutan. Setiap angkutan ada 12 penumpang.

Berapa banyak angkutan yang ada?

(pembagaian untuk kelas 2)

(24) Ibu membeli buku kemarin..

Harga semuanya 200 ribu rupiah Ibu mendapat potongan 20 ribu rupiah.

Ibu hanya membayar 180 ribu rupiah.

Berapa persen potongannya? (pembagian untuk kelas 3)

Soal(22) dan(23) tidak memenuhi keriteria komunikatif karena bahasanya tidak menciptakan konteks yang jelas dan logis. Pengunaan kata bungkusan pada soal (22) dan kata angkutan pada bagian pertanyaan tidak memperjelas pemahaman bagi siswa. Soal (24) ada bagian soal yang tidak perlu diadakan, yaitu Ibu hanya membayar 180 ribu rupiah.

Sebagaimana disampaikan di depan, selain disajikan materi tentang kriteria soal cerita, juga teknik penyusunannya yang meliputi 4 teknik, yaitu parafrase, analogi, modifikasi, dan generalisasi. Teknik parafrase adalah mengubah soal non-cerita menjadi soal cerita. Teknik analogi adalah menyusun soal cerita dengan mengacu pada contoh soal yang ada, tetapi materinya berbeda, misalnya soal untuk bilangan pecahan menganalog pada soal bilangan bulat. Teknik modifikasi adalah mengubah soal cerita yang sudah ada dengan memperbaiki bahasanya agar mudah dipahami siswa. Adapun teknik generalisasi adalah membuat soal cerita baru mengacu soal yang ada pada materi yang sama dengan mengganti besaran angka, simbol, atau perangkat matematika lainnya. Dari hasil wawancara dengan guru diperoleh informasi bahwa mayoritas guru kelas 1 dan 2 lebih suka menggunakan teknik parafrase dan generalisasi, sedangkan guru kelas 3 membuat soal cerita dengan teknik parafrase dan analogi. Hal tersebut didasarkan pada pernyataan beberapa guru sebagai berikut ini.

"Saya lihat di buku untuk kelas 1 soal ceritanya sudah bagus dan memenuhi kriteria bu dosen sehingga saya memilih meniru saja tetapi menggantinya dengan angka yang lain" (guru kelas 1).

\footnotetext{
"Kalau soal di buku guru tidak bagus, saya membuat sendiri dengan membuat soal angkanya dulu, tetapi kalau ada soal yang bagus di buku teks, saya gunakan untuk soal contoh" (guru kelas 2)
}

"Dengan mencontoh soal angka pada buku teks, saya lebih mudah mengubahnya menjadi soal cerita karena saya ingin membuat soal dengan menggunakan nama siswa di kelas sendiri supaya anakanak tertarik" (guru kelas 3)

Berikut ini disajikan contoh soal cerita hasil parafrase dan analogi yang dibuat guru kelas 3 .

\section{Soal non-cerita Soal cerita hasil parafrase \\ 126-108 = Santi sedang membaca buku Buku itu ada 126 halaman. Santi telah membca 108 ha-}


laman.

Berapa halaman yang belum dibaca Santi?

$\begin{array}{ll}\begin{array}{ll}\text { Soal cerita asal } \\ \text { Joko sedang flu. }\end{array} & \begin{array}{l}\text { Soal cerita hasil analogi } \\ \text { Jula-mula suhu }\end{array} \\ \begin{array}{ll}\text { Mula-mula suhu } \\ \text { badannya }\end{array} \\ \text { Badannya } 39^{\circ} \mathrm{C} . & \begin{array}{l}38,5^{\circ} \mathrm{C} . \text { Setelah minum } \\ \text { obat } \\ \text { suhu badannya turun }\end{array} \\ \text { Setelah minum } & 2,5^{\circ} . \\ \text { obat suhu badan- } & \text { Berapa derajat Celcius } \\ \text { nya turun } 2^{\circ} . \text { Be- } & \text { suhu Joko sekarang? } \\ \text { rapa suhu badan } & \\ \text { Joko sekarng? } & \end{array}$

\section{Simulasi pengajaran soal cerita dengan metode komunikatif}

Pada kegiatan ini diisi dengan penyampaian materi tentang metode pengajaran soal cerita secara komunikatif, yaitu membantu siswa untuk memahami isi soal cerita. Dalam penerapannya, metode pengajaran yang komunikatif meliputi metode menerjemahkan, menceritakan, dan menggambar. Metode menerjemahkan yaitu menyampaikan isi soal, terutama pada bagian tertentu yang menjadi penunjuk operasi hitung, (tidak semua bagian) soal ke dalam bahasa ibu pada siswa yang memiliki penguasaan bahasakedua kurangmemadai.Metode menceritakan yaitu menyam-paikan soal dengan menghadirkan unsur narasi yang mendukung, misalnya tokoh tambahan dan tempat serta waktu terjadinya peristiwa sehingga alur atau jalannya cerita lebih jelas dan menarik. Metode meng-gambar yaitu merepresentasikan kuantitaskuantitas pada soal cerita dari bentuk verbal disampaikan ke dalam bentuk visual. Metode ini cocok untuk kelaskelas rendah.
Setelah penyampaian materi tentang metode pengajaran soal cerita, guru diminta membuat sintak atau langkah-langkah pengajaran soal cerita. Salah satu sintak yang dirancang guru meliputi langkah-langkah sebagai berikut: (1) guru memberi garis besar materi yang telah dipelajari sebelumnya dan mengaitkannya dengan materi yang akan disampaikan, (2) guru membacakan soal cerita mereka dalam bahasa Indonesia, (3) guru menerjemahkan bagian tertentu soal ke dalam bahasa Jawa, (4) guru memberi contoh cara membuat persamaan matematika, (5) guru bersama siswa menghitung hasil persamaan tersebut, (6) guru membacakan soal yang lainnya, (7) guru menerjemahkan soal dari bahasa Indonesia ke dalam bahasa Jawa, (8) guru meminta salah satu siswa untuk menempelkan kartu bilangan pertama sesuai isi soal cerita pada papan tulis, (9) guru meminta siswa lain untuk menempelkan kartu angka kedua pada papan tulis, (10) guru meminta siswa lain untuk menempelkan kartu operasi hitung di tengah antara dua angka, (11) siswa dan guru mendiskusikan hasil persamaan matematika yang dibuat temannya, dan (12) guru meminta siswa lain untuk memilih dan menempel kartu angka untuk mengisi persamaan matematika. Berdasarkan sintak tersebut, guru memperagakan atau melakukan simulasi pengajaran soal cerita, sedangkan guru yang lain berperan sebagai siswa (peerteaching).

Ditinjau dari skenario dan praktik peer-teaching menunjukkan bahwa 
$70 \%$ lebih guru kelas 1, 2, dan 3 dapat memperagakan pengajaran soal cerita dengan metode komunikatif. Pada pelaksanaan simulasi, umumnya guru menggunakanmetode menerjemahkan dengan alasan penguasaan bahasa Indonesia siswa di kelasnya (yang nyata) masih rendah. Adapun penyebab rendahnya pemahaman siswa terhadap bahasa pada soal, yaitu bahasa Indonesia disampaikan beberapa guru sebagai berikut ini.

"Murid kelas 1 di sini belum bisa memamahami kata-kata bahasa Indonesia karena baru taraf belajar bahasa tersebut. Mereka tidak menempuh pendidikan TK atau PAUD sebelum ini. Saya terjemahkan soalnya supaya murid mudah memahami" (guru kelas 1)

"Murid saya bingung dengan kata-kata dalam soal karena arti sebuah kata yang sama bisa berbeda antara yang dipakai pada soal dan dalam komunikasi. Misalnya beli lagi artinya penjumlahan, diberikan artinya pengurangan, maka saya jelaskan isi soal itu dengan menceritakan kejadiannya dan saya sampaikan dalam bahasa Jawa" (guru kelas 2).

"Karena tinggalnya di desa, siswa sehariharinya hanya memakai bahasa Jawa. Maka kalau ada soal yang sulit dipahami siswa, saya sampaikan dalam bahasa Jawa dan saya buat situasinya seperti yang dialami sendiri” (guru kelas 3).

\section{Kinerja guru dan siswa dalam praktik pengajaran soal certita}

Sebagaimana diuraikan di depan, selain dilatih menyusun soal cerita, guru juga dilatih mengajarkan soal cerita buatannya di kelasnya dengan metode komunikatif. Oleh karena itu, setelah dilaksanakan workshop 1, 2, dan 3 dilakukan pendampingan pengajaran soal cerita matematika di kelas. Evaluasi terhadap keefektifan praktik mengajar yang dilakukan guru didasarkan pada tiga indikator yaitu
(1) penggunaan soal cerita buatannya sebagai materi ajark, (2) tingkat ketergantungan terhadap buku teks maksimal 50\%, dan (3) penggunaan metode komunikatif. Pengukurannya dilakukan melalui observasi dengan intsrumen check list. Data mengenai capaian ketiga indikator tersebut dapat dibaca pada Tabel 4.

Tabel 4. Kinerja Guru dalam Pengajaran Soal Cerita

\begin{tabular}{llll}
\hline \multicolumn{1}{c}{ Indikator } & \multicolumn{3}{c}{$\begin{array}{c}\text { Persentase guru yang } \\
\text { memenuhi indikator }\end{array}$} \\
\cline { 2 - 4 } & Kelas 1 & Kelas 2 & Kelas 3 \\
\hline $\begin{array}{l}\text { Menggunakan soal cerita } \\
\text { buatannya sebagai materi } \\
\text { ajar }\end{array}$ & 70 & 70 \\
\hline $\begin{array}{l}\text { Menggunakan buku teks } \\
\text { maksimal 50\% }\end{array}$ & 70 & 80 \\
\hline $\begin{array}{l}\text { Menggunakan metode } \\
\text { komunikatif secara tepat }\end{array}$ & 80 & 80 & 80 \\
\hline
\end{tabular}

Data pada Tabel 4 di atas menunjukkan bahwa untuk indikator ke-1, yaitu menggunakan soal cerita buatannya sebagai materi ajar, ada $80 \%$ guru kelas 1 yang mencapai target tersebut (8 dari 10 orang). Untuk guru kelas 2 dan 3, ada 70\% (7 dari 10 guru) yang menggunakan soal cerita buatannya. Ini menunjukkan guru kelas 1 adalah yang paling banyak dapat menggunakan soal cerita buatan sendiri sebagai materi ajar. Berdasarkan capaian indikator ke-2, yaitu menggunakan buku teks Matematika maksimal 50\%, data Tabel 3 menunjukkan bahwa persentase guru kelas 3 paling tinggi $(80 \%)$. Adapun untuk indikator ke-3, yaitu penggunaan metode komunikatif, $80 \%$ guru kelas 1, 2, dan 3 telah memenuhinya.

Untuk mengevaluasi keefek-tifan pembelajaran soal cerita juga dilihat 
dari kinerja semua siswa pada satu kelas yang menjadi tempat praktik. Pengukurannya didasarkan pada tiga indikator, yaitu semua siswa mampu (1) memahami seluruh soal cerita yang diajarkan guru, (2) membuat persamaan matematika minimal $50 \%$ dari soal cerita yang diberikan secara benar, dan (3) dapat menemukan hasil hitung minimal 50\% dari soal cerita yang diberikan. Data hasil pelaksanaan pembelajaran disajikan pada Tabel 5.

Tabel 5. Kinerja Siswa dalam Pengajaran Soal Cerita

\begin{tabular}{|c|c|c|c|}
\hline \multirow[t]{2}{*}{ Indikator } & \multicolumn{3}{|c|}{$\begin{array}{c}\text { Persentase kelas yang } \\
\text { memenuhi indikator }\end{array}$} \\
\hline & Kelas 1 & Kelas 2 & Kelas 3 \\
\hline $\begin{array}{l}\text { Semua siswa mema- } \\
\text { hami seluruh soal cerita } \\
\text { buatan guru }\end{array}$ & 60 & 70 & 80 \\
\hline $\begin{array}{l}\text { Semua siswa dapat } \\
\text { membuat persamaan } \\
\text { matermatika secarabenar } \\
\text { minimal } 50 \% \text { dari soal } \\
\text { cerita yang diberikan }\end{array}$ & 60 & 70 & 70 \\
\hline $\begin{array}{l}\text { Semua siswa dapat } \\
\text { menemukan hasil hitung } \\
\text { secara benar minimal } \\
50 \% \text { dari soal cerita yang } \\
\text { diberikan }\end{array}$ & 60 & 60 & 60 \\
\hline
\end{tabular}

Tabel 5 menunjukkan bahwa hanya $60 \%$ dari kelas 1 yang menjadi tempat praktik, siswanya dapat memahami soal cerita yang diajarkan, membuat persamaan Matematika dengan benar, dan menemukan hasil hitungnya seara tepat. Untuk kelas 2 , ada $70 \%$ kelas yang memenuhi indikator pertama dan kedua, namun hanya $60 \%$ yang memenuhi indikator Adapun untuk kelas 3, ada 80\% kelas yang siswanya dapat memahami soal cerita yang diajarkan, namun hanya $70 \%$ yang siswanya dapat membuat persamaan Matematika dengan benar, dan $60 \%$ kelas yang siswanya dapat menemukan hasil hitung secara benar pada minimal $50 \%$ soal cerita yang diberikan. sama dengan . persentase tertinggi adalah siswa kelas 1 . Begitu juga dengan yang dapat membuat terjemahan minimal $70 \%$ soal cerita ke dalam persamaan matematika secara tepat ada lebih dari $60 \%$ siswa, namun persentase tertinggi ada pada siswa kelas 2. Feneomena tersebut menunjukkan bahwa "tidak semua siswa yang dapat membuat persamaan Matematika secara benar, juga dapat menemukan hasil hitung secara tepat.

\section{Pembahasan}

Berdasarkan kualitas soal cerita buatan guru dapat dinyatakan lebih dari 70\% guru kelas 1, 2, dan 3 dapat membuat soal cerita sesuai kriteria pada operasi hitung hitung penjumlahan, pengurangan, perkalian, maupun pembagian. Dengan demikian, pelatihan dan pembimbingan penyusunan soal cerita yang dilakukan Tim IbM ini berhasil meningkatkan kompetensi guru dalam penyusunan soal cerita.

Ditinjau dari aspek muatan nilai karakter, sebagian besar soal cerita buatan guru memuat nilai kerja keras, disiplin, jujur, pedulisosial, kerja sama, peduli lingkungan, dan cinta tanah air. Berdasarkan hasil wawancara, nilai karakter yang disampaikan terbatas karena hal itu berkaitan dengan tema pelajaran Matematika kelas 1, 2, dan 3. Tema pelajaran lebih banyak berkaitan dengan bilangan bulat, bilangan pecahan, jarak, waktu, pecahan, suhu dan satuan ukuran lainnya (rim, lusin, 
gross, kodi).

Dibandingkan guru kelas 2 dan 3 , guru kelas 1 paling banyak dapat membuat soal dengan kualitas baik pada semua aspek, yaitu kebahasaan, unsur teks, unsur narasi, nilai karakter, dan kometensi dasar (KD). Bahkan pada aspek unsur teks, semua soal cerita buatan guru kelas 1 memuat unsur yang lengkap, yaitu ada bagian pembuka, peristiwa, dan pertanyaan. Semua guru kelas 2 juga dapat membuat soal dengan unsur teks yang lengkap.

Berbeda dengan guru kelas 1 dan 2, tidak semua guru kelas 3 dapat memenuhi indikator kelengkapan unsur teks dalam membuat soal cerita. Dari wawancara dengan guru diperoleh informasi bahwa penyebab guru kelas 3 tidak memuat unsur teks secara lengkap pada soal cerita buatannya berkaitan dengan contoh soal yang menjadi acuan guru tersebut, yaitu soal-soal pada buku teks. Artinya, guru tersebut mencontoh soal cerita tentang satuan hitung seperti lusin, kodi, dan rim pada buku teks Matematika dalam membuat soal cerita bagi siswanya. Contoh soal yang hanya memuat dua unsur teks antara lain:

(25) Ibu punya 4 lusin gelas. Berapa buah gelas Ibu?

(26) Ada 100 baju. Berapa kodi baju itu?

Unsur teks yang dihilangkan adalah bagian pembuka yang berfungsi sebagai pembangun konteks. Padahal, konteks yang jelas akan membantu anak-anak dalam mengonstruksi pemahamannya terhadap isi soal mengingat soal cerita adalah menghubungkan Matematika dan dunia nyata (Caldwell, \& Godin, 2005; Stein \& Glenn, 2002). Adapun pembangun konteks yang paling utama adalah bagian pembuka sebagaimana disampaikan Gerofsky (1996), maka agar lengkap unsurnya, soal (25) dan (26) dapat dibuat sebagai berikut.

(27) Ibu suka mengoleksi gelas. Ibu punya 4 lusin gelas. Berapa buah gelas Ibu?

(28) Pak Karjo adalah pedagang pakaian. Hari ini ia membeli 100 baju. Berapa kodi baju yang dibeli Pak Karjo?

Kesuksesan para guru kelas 1, 2, dan 3 SD di Kecamatan Cepogo dalam penyusunan soal cerita dapat dikaitkan dengan teknik yang diterapkan, yaitu sebagian besar guru menggunakan teknik parafrase. Pengubahan dari soal noncerita menjadi soal cerita dilakukan dengan prosedur: (1) guru membuat soal non-cerita sesuai KD dan materi ajar, (2) guru memilih unsur narasi yang meliputi aktor dan setting sesuai tema dan subtema pelajaran; kemudian (3) guru membuat soal berdasarkan kriteria yang diberikan Tim dengan kata-kata sendiri. Teknik ini dipandang guru sebagai cara paling mudah untuk menyusun soal cerita yang sesuai kriteria pada unsur narasinya, yaitu dengan menggunakan nama siswa sebagai tokoh dan kegiatan siswa sebagai setting. Hal tersebut merupakancarayang tepatagarkonteks soal sesuai dengan pengalaman siswa sebagaimana temuan Zan (2010) dan Bairac (2008).

Pada kegiatan simulasi pengajaran soal cerita yang dilakukan 
secara peer-teaching, 70\% lebih guru kelas 1, 2, dan 3 dapat menerapkan metode pengajaran yang komunikatif. Sebagaimana yang diuraikan di bagian depan, dalam penerapannya, metode komunikatif direalisasikan melalui metode menerjemahkan, menceritakan, dan menggambar. Semua guru kelas 1 dan 2 menerapkan metode menerjemahkan untuk membantu siswa agar lebih memahami isi soal. Artinya guru menyampaikan bagian tertentu (atau seluruhnya) pada soal cerita berbahasa Indonesia melalui bahasa Jawa. Hal tersebut disebabkan penguasaan bahasa Indonesia siswa kelas 1dan 2 SD di Kecamatan Cepogo masih rendah. Adapun guru kelas 3, selain menerapkan metode menerjemahkan, juga metode menceritakan (dengan bahasa Indonesia dan bahasa Jawa). Contoh penerjemahan yang dilakukan guru kelas 2 sebagai berikut.

\begin{tabular}{ll}
\hline \multicolumn{1}{c}{ Soal Cerita } & $\begin{array}{c}\text { Penerjemahan bagian } \\
\text { soal yang sulit ke dalam } \\
\text { Bahasa Jawa }\end{array}$ \\
\hline Tema : Tinggi badan & Aku mempunyai seorang \\
Aku mempunyai seorang & kakak. Masku 10 cm \\
kakak. Kakakku 10 cm & luwih dhuwur tinimbang \\
lebih tinggi daripada aku. & aku. Masku dhuwure 1,68 \\
Tingggi badan kakak 1,68 & meter. Pirang sentimeter \\
m. Berapa sentimeter & dhuwurku? \\
tinggi badan aku? & \\
\hline
\end{tabular}

Penerjemahan merupakan salah satu metode yang tepat dalam pembelajaran soal cerita di kelas awal, di mana siswa pada saat yang sama sedang mempelajari bahasa kedua (Bernardo \& Calleja, 2005; Carpenter, Hiebert, \& Moser, 1983). Penerapan salah satu jenis metode komunikatif tersebut utamanya cocok untuk soal-soal yang sulit, misalnya tipe perbandingan seperti contoh di atas sebagaimana temuan Sumarwati dan Budiyono (2015) serta Sumarwati (2007).

Berkaitan dengan kinerja guru pada praktik pengajaran soal cerita di kelas, lebih dari $60 \%$ guru kelas 1, 2, dan 3 telah menggunakan soal cerita buatannya sendiri sebagai materi, meminimalkan ketergantungannya pada buku teks Matematika, dan menggunakan metode komunikatif. Dengan menggunakan soal cerita buatan sendiri sebagai materi otomatis mengurangi ketergantungan guru terhadap buku teks Matematika. Hal itu harus dilakukan mengingat soal cerita dalam buku teks Matematika yang digunakan guru SD di Kecamatan Cepogo selama ini tidak memenuhi kriteria sebagai soal yang cocok bagi siswa pedesaan, terutama pada aspek kebahasaan dan unsur narasinya. Fenomena tersebut mempertegas hasil penelitian Sumarwati (2014) dan Sumarwati (2013) bahwa soal cerita dalam buku teks Matematika belum memenuhi kriteria sebagai soal yang komunikatif.

Berkaitan dengan metode komunikatif yang digunakan peserta kegiatan IbM pada praktik di kelasnya, metode utama yang digunakan guru kelas 1, 2, dan 3 adalah metode penerjemahan sebagaimana yang diterapkan pada simulasi pengajaran secara peer teaching. Akan tetapi, metode tersebut dipadukan dengan metode menceritakan pada soal cerita yang kompleks, materi baru, atau konteksnya asing bagi siswa. Misalnya penggunaan kata maju dan 
mundur untuk menunjuk operasi hitung penjumlahan dan pengurangan pada siswa kelas 1, materi tentang perubahan suhu pada siswa kelas 2, serta konsep ketinggian dengan bilangan negatif sebagai jarak di bawah permukaan air laut pada siswa kelas 3. Bersama metoede lainnya, metode menceritakan perlu digunakan guru untuk memperjelas konteks sebagaimana yang dinyatakan Bitter (2009)

Ditinjau dari kinerja siswa pada praktik pengajaran soal cerita dengan metode komunikatif, lebih dari $60 \%$ kelas menunjukkan peningkatan dalam memahami isi soal cerita, membuat persamaan Matematika secara benar, dan menemukan hasil hitung secara benar terhadap seluruh soal cerita yang diberikan. Dengan demikian, pelatihan dan pendampingan yang dilakukan Tim ini bermanfaat untuk meningkatkan kinerja guru maupun siswa karena berdasarkan identifikasi masalah ditemukan bahwa metode pembelajaran soal cerita matematika yang diterapkan guru selama ini belum bisa membantu siswa untuk memahami isi soal cerita atau belum komunikatif. Materi soal cerita matematika lebih banyak diajarkan dengan menggunakan metode langsung atau penugasan. Akibatnya siswa kurang termotivasi dan kurang menyukai pelajaran Matematika (bahkan takut pada Matematika) serta mengalami kesulitan memecahkan soal cerita. Hal ini sejalan dengan temuan Sumarwati, Budiyono, dan Atikah (2018) dan Bitter (2009) bahwa kunci sukses pembelajaran soal cerita adalah menumbuhkan rasa tertarik siswa melalui cerita-cerita.

\section{SIMPULAN}

Berdasarkan deskripsi di atas dapat simpulkan bahwa pelatihan dan pendampingan yang dilakukan Tim IbM dapat meninkatkan kompetensi guru dalam menyusun soal cerita dan mengajarkan soal cerita buatannya dengan metode yang komunikatif sehingga membantu siswa untuk memami isi soal tersebut. Hal ini menunjukkan adanya peningkatan kinerja siswa dibandingkan sebelum guru mengikuti pelatihan dan pendampingan pada kegiatan IbM ini.

Pelatihan dan pembimbingan penyusunan soal cerita yang dilakukan oleh Tim berhasil meningkatan kompetensi guru dalam soal cerita yang sesuai dengan karakteristik siswa pedesaan pada aspek kebahasaan, konteks, nilai karakter, dan KD. Kegiatan tersebut dilakukan guru melalui teknik parafrase, analogi, generalisasi, dan modifikasi. Dengan demikian, kompetensi menyusun soal cerita di sini menunjuk pada aktivitas guru dalam membuat soal cerita sendiri dengan teknik tertentu dengan memperhatikan kompetensi linguistik siswa atau dalam bahasa sesederhana mungkin sehingga mudah dipahami dan diterjemahkan benar.

Pembuatan soal cerita oleh guru yang disesuaikan dengan kompetensi komunikatif siswa dan penerapan metode pengajaran secara komunikatif dapat meningkatkan kualitas pembelajaran Matematika. 
Para siswa yang semula mengalami kesulitan dalam menerjemahkan bahasa soal cerita ke dalam persamaan matematika sehingga tidak suka pada pelajaran tersebut menjadi berkurang kesulitannya dan menyukainya.

Dari hasil evaluasi terhadap kegiatan praktik pengajaran menunjukkan baru $60 \%$ guru kelas 1 , 2 , dan 3 yang sukses memenuhi tiga indikator, yaitu menggunakan soal cerita buatan sendiri sebagai materi ajar, meminimalkan ketergantungan pada buku teks Matematika, dan menerapkan metode komunikatif. Namun demikian, kondisi ini jauh lebih baik dibandingkan kondisi sebelum diadakan pelatihan karena dari hasil wawancara diketahui bahwa selama ini mereka tidak tahu/bisa membuat soal cerita, menggunakan buku teks sebagai satu-satunya sumber pembelajaran Matematika, serta tidak tahu metode mengajarkan soal cerita. Dengan kata lain, guru tergantung $100 \%$ terhadap buku teks meskipun diketahui sebagian soal cerita dalam buku teks tidak relevan dengan kompetensi komunikatif siswa.

\section{DAFTAR PUSTAKA}

Bairac, R.(2008). Some Methods for Composing Mathematical Prob-lems. In J.A. van Dale (ed.), Primary and Middle School Mathematics: Teaching Develop-mentally. New York: Addison Wesley Longman. 124-133.

Bernardo, A.B.I. \& Calleja, M.O. (2005).The Effects of Stating Problems in Billingual Students' First and Second Languages on Solving Mathematical Word Problems.The Journal of
Genetic Psychology, 166 (1), $117-128$.

Bitter, G. G. (2009). Mathematics Methods for Elemenrtary and Middle School.Singapore: Simon \& Schuster.

Budiyono. (2008). Identifikasi Kesalahan Mengerjakan Soal Cerita dalam Pembelajaran Matematika Siswa Sekolah Dasar. Paedagogia, 11 (1): 129-140.

Caldwell, J.H. \& Godin, G.A. (2005). Variables Affecting Word Problem Difficulty in Primary School Mathematics.Journal for Research in Mathematics Education.10(5): 323-336.

Carpenter, T.P., Hiebert, J. \& Moser, J.M. (1983). The Effect of Instruction on Children's Solutions of Addition and Substraction Word Problems. Education Studies in Mathematics, 14(1), 55-72.

Gerofsky, S. (1996). A Linguistic and Narrative View of Word Problems in Mathematics Education. For the Learning of Mathematics, 16(2), 36-45.

Raharjo, M.,Ekawati,E., \& Rudiyanto, Y. (2009). Modul Matematika SD Program BERMUTU: Pembela-jaran Soal Cerita di $S D$. Departemen Pendidikan Nasional, Direktorat P4TK, PPPPTK Matematika.

Stein, N.L. \& Glenn, C.G. (2002). An Analysis of Story Comprehension in Primary School Children. Language Arts Journal, 7(9),492-501.

Sukamto, Sukardjono, \& Ngatoilah, I. (2008). Diagnosis Kesulitan Belajar Matematika dan Remediasinya melalui Penelitian Tindakan, Jurnal Kependidikan, 2, 187-208.

Sumarwati, Budiyono, \& Atikah. (2018). Words Problem Based Creation for Thematic 
Mathematical Stories: A Collabo-rative Action Research, Science, Engineering, Education, and Development Studies (SEEDs): Conference Series, 2(2), 181-191

Sumarwati \& Budiyono. (2015). Struktur Semantik Soal Cerita Matematika untuk Siswa Kelas Rendah Sekolah Dasar, Jurnal Litera, 14(2), 262-276.

Sumarwati. (2014). The Types of Word Problem Discourse Structure in Mathematics Textbook Presented in Indonesian for Primary School Students, Journal of Education and Practice, 5 (12), 234-255

Sumarwati. (2013). Soal Cerita dengan Bahasa Komunikatif untuk Meningkatkan Kualitas Pembela-jaran Matematika Sekolah Dasar. Jurnal Ilmu pendidikan, 19 (2), 127-136.

Sumarwati. (2007). Penyederhanaan Bahasa untuk Meningkatkan Kemampuan Memecahkan Soal Cerita Matematika pada Siswa SD. Jurnal Pancaran Pendidikan, 20 (2), 128-135.

Zan, R. (2010). The Crucial Role of Narrative Thought in Understanding Word problems. MAVI (Mathematical Views) 16th Conference 26-29 June 2010, Talinn - Estonia. 